\title{
Foreignization and its Contributions to the Translation of Weapons, Magic and Spells in W.J.F Jenner's Version of Journey to the West
}

\author{
Zhong Deng \\ Foreign Language School \\ Southwest Minzu University \\ Chengdu, China
}

\author{
Jingjing Jiang \\ Foreign Language School \\ Southwest Minzu University \\ Chengdu, China
}

\begin{abstract}
Weapons, magic and spells in Journey to the West not only play a crucial part in immortal-and-demon fights but also contain profound culture connotations which pose great difficulty to non-Chinese readers. This paper, by analyzing Jenner's English translation on weapons, magic and spells from the perspective of translation strategies, finds out that foreignization is the main means to deal with such alien items and cultural barriers alongside, thus facilitating the dissemination of Chinese culture into English-speaking countries and areas.
\end{abstract}

Keywords-foreignization; Jenner's translation of Journey to the West; weapons; magic and spells

\section{INTRODUCTION}

Journey to the West, as one of the four masterpieces of Chinese classical novels, is of lasting significance in Chinese literature and enjoys a great reputation across the globe. With the increasing abundance in research on the translation versions of this novel, the themes, characters, plots, religions and some other topics of Journey to the West have been gradually known in the western societies, but there are still problems that prevent readers from achieving a good understanding of the cultural implications of this novel. Such problems are in particular manifest in the comprehension of weapons, magic and spells that appear in every single chapter as sometimes a determining factor in the battles between the monks (mainly Sun Wukong) and the demons. More specifically, thanks to the publications and promotions of various versions of Journey to the West, the large number of weapons, magic and spells are brought closer to western readers, commonly believed to add abundance, appeal and fantasy to the stories, but the shortening of the distance does not automatically promise an improvement of the understanding of the specific cultural implications associated with such items, thus resulting in either inappropriate interpretations or simplistic assertions with regard to their roles in and contributions to the narration. By contrast, W.J.F Jenner's English version, perhaps the one that has been most

This paper is supported by SMU Students' Innovation an Entrepreneurship Program. Project Title: A Cognitive Approach to the Meanings of Devils in Journey to the West and their Translation in the English-speaking World (No. 201710656029). frequently read and studied in the English-speaking societies, makes a difference as it to a large extent lessens or even eliminates the cultural barriers posed by the weapons and spells and seems to be more easily accessible to the readers than many other versions. Why is the case? Interestingly, however, previous research on this version has not touched upon this question, but has focused on a wide range of familiar issues such as the titles of chapters, names of people and demons, religious terms, idioms, poems and so forth (Wang 2013). Not denying the significance and contributions of such studies, we argue that an investigation into how the weapons, magic and spells are rendered in Jenner's version is equally valuable because the translation strategies Jenner has applied not only account for the success of his translation endeavors, but also may serve as a model for other translators, Chinese or western, to produce desirable translation versions of other literary works of China

\section{DOMESTICATION AND FOREIGNIZATION}

Domestication and foreignization were put forward in The Translator's Invisibility (1995) by American scholar Lawrence Venuti. Domestication was designated as "an ethnocentric reduction of foreign text to TL cultural values, bringing the author back home", and foreignization as "an ethnodeviant pressure on those (TL culture) values to register the linguistic and cultural difference of the foreign text, sending the reader abroad" (Venuti 1995). In other words, domestication refers to TL culture-oriented translation in which unusual expressions to the target culture are exploited and turned into some familiar ones so as to make the translated texts intelligible and suitable for the target readers; nevertheless, foreignization is SL culture-oriented translation which strives to preserve to the original flavor as much as possible in order to transfer the source language and culture into the target one (Chen 2015), i.e. domestication gives priority to target culture and readers while foreignization conforms to source culture as well as readers in the face of vocabulary vacancy and cultural conflict/difference between two languages in the realm of translation. These two strategies are of the paramount importance and debatable value from the perspective of many Chinese translators and scholars. Sun (2002) maintained that domestication is 
synonymous with free translation and foreignization is equivalent to literal translation to a large extent. However, Huang (2010) claimed that the dichotomy of domestication and foreignization is distinguished from the distinction of literal and free translation in that the latter focuses on the content, form and style between source language (SL) and target language (TL) while not merely is the former concerned with the content, form, style but also pays more attention to the cultural features reflected on both SL and TL, e.g. religion, poetry, proverbs in Journey to the West. In a word, domestication and foreignization are far more complicated than literal and free translation.

\section{FOREIGNIZATION IN JENNER'S VERSION}

Owing to a wide variety of weapons, magic and spells in Journey to the West, we first read and collect both Chinese and English descriptions on such items in Jenner's version. Then such descriptions are classified into two types: weapons, magic and/or spells. Putting Jenner's version into perspective we find out the application of different translation strategies on each group in three tables given in "Table I".

TABLE I. WEAPONS AND THEIR ENGLISH TRANSLATION (JENNER 2003)

\begin{tabular}{|l|l|}
\hline \multicolumn{1}{|c|}{ Weapons } & \multicolumn{1}{c|}{ Jenner's version } \\
\hline 如意金箅棒 & as-you-will gold-banded cudgel \\
\hline 如意钩 & as-you-will hook \\
\hline 九齿钉耙 & nine-toothed/ pronged rake \\
\hline 九环锡杖 & nine-ringed monastic/monk's staff \\
\hline 九瓣铜锤 & nine-knobbed copper mace \\
\hline 三棱简 & three-edged mace \\
\hline 火尖枪 & fire-tipped spear \\
\hline 长杆枪 & long-handled spear \\
\hline 黑缨枪 & black-tasseled spear \\
\hline 蟠龙拐 & dragon-headed stick \\
\hline 月牙铲 & crescent-bladed halberd \\
\hline 铁蔟㢣 & spiked iron club \\
\hline 降妖杖 & demon/ ogre -quelling staff \\
\hline
\end{tabular}

\begin{tabular}{|c|c|}
\hline Weapons & Jenner's version \\
\hline 照妖镜 & demon-revealing mirror \\
\hline 斩妖剑 & demon-beheading sword \\
\hline 砍妖刀 & demon-hacking cutlass \\
\hline 缚妖索 & demon-binding rope \\
\hline 降魔杵 & demon-quelling pestle \\
\hline 捣药杵 & drug/medicine-pounding pestle \\
\hline 宣花钱斧 & flower-scattering battle-axe \\
\hline 定风丹 & Wind-fixing/ settling Pill \\
\hline 狼牙棒 & wolf-tooth mace/cudgel \\
\hline 四明铲 & four-bright halberd \\
\hline 方天戟 & heaven-square halberd \\
\hline 火轮儿 & fire-wheel \\
\hline 辟火罩 & Anti-fire Cover \\
\hline 绣球 & embroidered ball \\
\hline 倒马毒 & horse-killer poison \\
\hline 竹节鞭 & bamboo-link flail \\
\hline 七星剑 & Seven-star Sword \\
\hline 幌金绳 & Dazzling Golden Cord \\
\hline 飞龙杖 & Flying Dragon Staff \\
\hline 金刚环 & Diamond Jade Bangle \\
\hline 芭蕉扇 & Plantain Fan \\
\hline 混铁棍 & rough iron mace \\
\hline 一副金铙 & a pair of bronze cymbals \\
\hline 两把青峰宝剑 & a pair of blue-tipped swords \\
\hline 双股剑 & a pair of swords \\
\hline 三股钢叉 & steel trident \\
\hline 十八粒金丹砂 & eighteen grains of golden cinnabar sand \\
\hline 人种袋 & human seed bag \\
\hline 绣花针 & embroidery needle \\
\hline 紫金红葫芦 & gold and red gourd \\
\hline 紫金铃 & purple gold bells \\
\hline 紫竹篮 & a basket made from purple bamboo \\
\hline 五彩霞衣 & a dress of many colours \\
\hline 莲花台 & lotus throne \\
\hline 阴阳二气瓶 & the Male and Female Vital Principles Jar \\
\hline $\begin{array}{l}\text { 羊脂玉净瓶 (太 } \\
\text { 上老君) }\end{array}$ & $\begin{array}{l}\text { a vase of muttonfat jade(Lord Lao Zi of the } \\
\text { Supreme Ultimate) }\end{array}$ \\
\hline $\begin{array}{l}\text { 净 瓶（观音菩 } \\
\text { 萨） }\end{array}$ & $\begin{array}{l}\text { vase of pure water/pure vase(the Bodhisattva } \\
\text { Guanyin) }\end{array}$ \\
\hline 如来的金钵孟 & the Tathagata's golden begging bowl \\
\hline
\end{tabular}

TABLE II. MAGIC AND/OR SPELlS AND THEIR ENGLISH TRANSLATION (JENNER 2003)

\begin{tabular}{|c|c|}
\hline Immortals' Magic & Jenner's version \\
\hline 《紧绳咒》 & Rope-tightening Spell \\
\hline 《松绳咒》 & Rope-loosening Spell \\
\hline 《紧䇫咒》 & Band-tightening Spell \\
\hline 《金䇫咒》 & Gold-band Spell \\
\hline 避水诀 & water-repelling magic, water- averting spell \\
\hline 辟火诀 & fire avoidance spell \\
\hline 金子心肝, 银子肺腑, 铜头铁背 & a heart and liver of gold, lungs of silver, a brazen head, an iron back \\
\hline 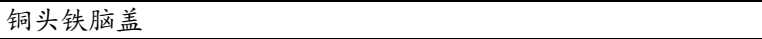 & a skull of bronze and iron \\
\hline 火眼金睛 & fiery eyes with golden pupils \\
\hline 筋斗云 & somersault cloud \\
\hline 腾云驾雾 & riding clouds and mists \\
\hline 有三十六般变化 & perform/do thirty-six transformations \\
\hline 有七十二般变化 & perform/do seventy-two transformations \\
\hline 香风（八大金刚） & fragrant wind, scented breeze (Eight Vajrapanis) \\
\hline (那太子) 使出法来将身一变, 变作三头六臂, 手持六般兵器 & ...used magic to give himself three heads and six arms that wielded six weapons \\
\hline
\end{tabular}




\section{Immortals' Magic}

二郎 (神) 圆睁风眼观看，见大圣变了麻雀儿，钉在树上，就收了 法象, 粠了神锋, 卸下弹弓, 摇身一变, 变作个饿鹰儿, 抖开 翅, 飞将去扑打。

In "Table I", jiu huan xi zhang(九环锡杖) is translated into nine-ringed monastic/monk's staff, xi(锡)interpreted as "monastic/monk's staff", for in Chinese it refers to the kind of staff held by Buddhist monks. Here, the translating strategy is foreignization and the translated phrase helps both Chinese and English readers get a good knowledge of it. Jiu chi ding pa (九齿钉耙), san leng jian (三棱简), pan long guai (蟠龙拐) are rendered respectively as nine-toothed rake, threeedged mace, dragon-headed stick, and all modifiers preceding nouns are the combinations of nouns A and nouns B -ed forms; likewise, xiang yao zhang (降妖杖), dao yao chu (捣药杵), jin gu zhou (紧篗咒) are separately demon-quelling stuffs, drug-pounding pestle, Band-tightening Spell, and the modifiers are the blends of nouns A and verbs B -ing forms. Such expressions not only display a uniform patterning but also word-for-word translation. Phrased and sentences translated literally are too many to enumerate.

On the other hand, Yue ya chan (月牙铲) is crescentbladed halberd, "halberd" in Chinese ji (戟) being different from "spade/shovel" in chan (铲). The translator translates the weapon according to his own understanding; nevertheless his version seems far from the original meaning. Similarly, dao ma du (倒马毒) is translated literally into horse-falling poison, where dao (倒) matches "falling" so that it is construed as "killer" ,thus manifesting the method of free translation as well. Jin gang zhuo (金刚琢) is Diamond Jade Bangle in conformity with his comprehension, in which zhuo (琢) is nonequivalent to shou zhuo /jiao zhuo (手锡/脚镯) in "bangle". We assume that it may be a "ring" that can contain miscellaneous powerful weapons by reading the context. To sum up, such English versions of Chinese characters by free translation are to some degree incorrect or inexact. We are not opposed to the application of free translation but simply point out the translator's misunderstanding of the original text is also evident in his version.

$\mathrm{Ru}$ yi jin gu bang (如意金䉗棒) and ru yi gou (如意钩) exhibit the material-related connotations for ru yi (如意) originating from Sanskrit refers to an S-shaped ornamental object usually made of jade as a symbol of good luck. In China, ru yi (如意) conveys people's good wishes. The two weapons are translated into "as-you-will gold-banded cudgel" and "as-you-will hook" literally so that the readers can get to know about the function of the weapons from Jenner's version; this also helps to disseminate the unique tool culture to English readers (Han 2016). Lian hua tai (莲花 台) in "lotus throne" is associated with Chinese Buddhism and yin yang (阴阳) in "the Male and Female Vital Principle" is related to Chinese Taoist philosophy, which is a mirror of Chinese culture as well. Bo yu (钵孟) in "begging bowl" is usually used by the Buddhists. San mei zhen huo (三昧真火) in "True Samadhi Fire" translated by both literal transference ("True Fire") and transliteration ("Samadhi" by Sanskrit)
Erlang opened his phoenix eyes till they were quite round and looked about him. He saw that the Great Sage had changed himself into a sparrow and was perching on a branch; so he put off his magical appearance, threw down his divine trident, and took the pellet bowfrom his waist. Then he shook himself, changed into a kite, spread hiswings, and swooped in to attack.

appear frequently in Chinese classical literature and Taoist culture. Yang zhi yu (羊脂玉) in “muttonfat jade” is of top quality among various jade thus being valued since ancient times, when only the upper classes in imperial court were entitled to such quality jade standing for Chinese people's aesthetics. When translating feng tiao yu shun(风调雨顺), yue mao hua rong (月貌花容), jun qiao wen ren(俊俏文人) as idioms comprised of four Chinese characters the translator interprets them in line with their literal meanings thereby spreading authentic Chinese culture to the English readers. Feng tiao yu shun(风调雨顺) is translated into favorable weather and abundant harvests, which signifies Chinese agricultural culture in which Chinese farmers attach great importance to the climate promising a bumper harvest or crop failure.

\section{CONTRIBUTIONS OF FOREIGNIZATION}

The weapons and magic of immortals and demons are not merely used as arms in fights to attack their opponents as well as defend themselves but also are endowed with abundant and profound Chinese cultural meanings distinguished from those specific to English culture (Chen 2010). For instance, Sun Wukong's as-you-will gold-banded cudgel is related to a Chinese legend, namely, it is one of the nails that $\mathrm{Yu}$ the Great used to fix the depths of rivers and seas when he brought the waters under control (Jenner 2003). The nine-knobbed copper mace was transformed from the Bodhisattva Guanyin's lotus associated with Chinese Buddhist culture. The gold and red gourd possessed by Lord Lao $\mathrm{Zi}$ of the Supreme Ultimate serves as a container in which Taoist alchemy medicines were put (Liu 2010). The vase of pure water/pure vase of Guanyin appeared several times in the novel and it helped the Monkey King get rid of plights, thus representing Chinese people's worship and faith in Guanyin. The mere mention of gold-banded cudgel reminds us of the Monkey; when speaking of the ninetoothed/ pronged rake the Pig Zhu Bajie occurs to us. A piece of weapon or a sort of magic is always reminiscent of certain character in the novel and it has become a symbol, which is of literary significance. Many magical weapons and spells alike, as a result of being interpreted as the Chinese cultural projection, can help deepen culture connotations to this immortal-and-demon novel.

The above-listed weapons, magic and spells abound with profound cultural features and are described as cultureloaded items. The translator adopts mainly foreignization for these culture-related words with the aim of the full embodiment of exotic culture in the masterpiece Journey to the West. The translated text preserves Chinese cultural elements without interpretation or annotation thus introducing original flavor of Chinese culture into English countries. The version is chiefly Chinese culture-oriented i.e. the SL culture-oriented. Upon knowing these, we are justified in concluding that foreignizaion, rather than 
domestication, is what Jenner has mainly drawn on, by means of which he achieves the fidelity of the source text and satisfies the TL readers' desire for reading and comprehending the SL culture. In this way, the source culture can be transferred into the target culture and further enrich the target culture as well as the target language. In other words, foreignization brings English readers (the TL readers) brand-new cultural experience so that they are offered a chance to feel the distinctiveness of Chinese culture (the SL-culture) and consequently this may boost the external spread and transplantation of Chinese culture into English countries. Such benefits cannot be achieved given that domestication is applied on the English translation of weapons, magic and spells. That is why foreignization is a better choice in the process of translating culture-specific terms including magical weapons and spells.

For a deepened insight into how foreignization works and benefits, we provide here several explanations as follows:

- It is advisable for the TL readers to expose themselves to alien cultures, which is usually their aim for reading translated texts.

- Translators should not underestimate the TL readers' intelligence and imagination with regard to foreignness of the TL-culture. TL readers are expected to know better the SL-culture since TL readers are capable of acquainting themselves with the SL-culture at the age of globalization and information when people from different countries and various cultural backgrounds have established increasingly frequent conversations with each other in pace with more frequent exchanges among nations.

- The transplantation of the SL-culture into the TL will help enrich the expressions and culture of the TL.

- Translation is supposed to perform the function of cultural communication, which is also its principal objective.

- Fidelity is not fulfilled unless the translated text mirrors the phenomena of the source language and culture.

Accordingly, the ground on which domestication is applied is the noticeable specificity/difference between the SL and TL cultures, that is, translators are unable to take full account of linguistic and cultural elements both SL and TL when translating one language into the other; whereas, the motivation of foreignizing translation is the openness and permeation of language-culture relations for it is an inclusive system enough to embrace enormous differences beyond usual imagination (Wang 2004). As addressed above, magical weapons and spells, as one of key traits of Journey to the West, endow this novel with fantasy and enrich its characters. More noticeably, abundant and profound Chinese cultural concepts are embodied by weapons, spells and magic. Although the English translation of them still remains to be deciphered, the added exotic taste and intriguing reading experience may overshadow the inconvenience caused by efforts of understanding these items. As a result, a closer look at Jenner's version of weapons, spells and magic from the perspective of translation strategies-domestication and foreignization-demonstrates far-reaching implications of Chinese culture and cultural communication from China to English-speaking countries. It is the application of such a translation strategy that makes Chinese culture relevant to weapons, spells and magic open to the world and helps English-speaking people obtain their own knowledge of our culture through reading ancient Chinese novels like this.

\section{CONCLUSION}

To sum up, we find out Jenner mainly employs the strategy of foreignization in the English translation of weapons, magic and/or spells in Journey to the West. We believe it is advisable to translate these culture-specific words and phrases by adopting this translation strategy. Applying foreignization into such items displaying profound cultural characteristics retains the original taste of the SLculture and infuses the flesh and intriguing elements into the TL-culture thus promoting the cross-cultural exchange. This process is perceivably more complicated than what is stated in this paper, but what we have illustrated may serve as a pioneering effort to address how translation strategies may be transformed into added appeal of a culture that is basically different from what the target readers are soaked up with. In this sense, this paper is expected to make some contributions to the further transmission of Chinese culture into English countries.

\section{REFERENCES}

[1] Chen Gaowa, A Tentative Analysis of Domestication and Foreignization in Translation [J]. English on Campus, 2015(20).

[2] Chen Yufeng, A Study on the Weapons, Flubbers and Magic of "Journey to the West". [D]. Shandong Normal University, 2010.

[3] Guo Jianzhong, The Cultural Factors in Translation: Foreignization and Domestication. [J]. Journal of Foreign Languages, 1998 (02).

[4] Han Yuanyuan. A Study on the C-E Translation of the CultureLoaded Words in Xi Youji from the Perspective of Skopos TheoryBased on Jenner's English Version of Xi Youji. [D]. Xi'an International Studies University, 2016.

[5] Huang Yanchun, Some Major Points of Foreignization and Domestication. [J]. Foreign Language Research, 2010 (04).

[6] Liu Yuguo, Huang Yan. The Mythical Battle of Wits between Gods and Demons of "Journey to the West". [J]. Journal of Hechi University, 2010 (06).

[7] Sun Zhili, China's Literary Translation: from Domestication to Foreignization. [J]. Chinese Translators Journal, 2002 (01).

[8] Venuti, Lawrence. The Translator's Invisibility: A History of Translation[M]. London and New York:Routledge, 1995.

[9] Wang Ping, Domestication $\mathrm{n}$ and Foreignizatio: Achieving the Same Goal by Different Translation Strategies. [J].Journal of Fuzhou University(Edition of Philosophy and Social Science), 2004 (01)

[10] Wang Liping, A Comprehensive Study on Translation of "Journey to the West": Review and Prospect. [J]. Journal of Hubei University of Education,2013 (04)

[11] Wu Cheng'en and Jenner.W.J.F (trans), Journey to the West (Chinese-English). [M]. Beijing: Foreign Language Press,2003. 